\title{
AFFECTED SIB PAIR METHOD FOR SEARCHING MAJOR GENE IN MULTIFACTORIAL DISEASE*
}

\author{
Norikazu YASUDA ${ }^{1}$ and Takehiko SASAZUKI ${ }^{2}$ \\ ${ }^{1}$ Division of Genetics, National Institute of \\ Radiological Sciences, Chiba 260, Japan \\ ${ }^{2}$ Department of Human Genetics, Medical Research Institute, \\ Tokyo Medical and Dental University, Tokyo 113, Japan
}

\begin{abstract}
Summary The affected sib pair method to detect the effect of HLAlinked disease genes has been explained from a practical viewpoint. It is based on the assumption that HLA haplotypes as marker are used to trace the inheritance pattern of closely linked disease susceptibility genes. Looking at families in which two or more siblings had disease in question, the nonrandom zygotic assortment of HLA haplotypes would be a demonstration of disease gene.

Application of affected sib pair method to Graves' disease had delineated that two genes, HLA-lined and Gm-linked, are responsible for manifestation of the disease as recessive inheritance with high penetrance.
\end{abstract}

\section{INTRODUCTION}

Recent findings of HLA-associated disease have opened an avenue to look for gene(s) that would express major effect in multifactorial disease. Human leucocyte antigens or histocompatibility genes have been revealed to have so enormous polymorphism as well as important immunological functions, particularly surveillance of external agents against cell (Frelinger and Schreffer, 1975; Bodmer, 1972; Bodmer and Bodmer, 1978; Barnstable et al., 1979; Dausset, 1981, and Thomson 1981), that HLA could be very useful as a genetic marker to disentangle genetic mechanism involved in onset of disease, assuming that the association between HLA and disease was due to linkage disequilibrium.

One approach in this direction recently developed is so called affected sib pair method. The purpose of this paper is to explain the method for practical use, illustrated with Graves' disease.

Received February 21, 1982

* This study was supported in part by a grant for the Intractable Diseases from Ministry of Health and Welfare, Japan. 
THE MODEL

The use of multiple case family studies to detect the effect of HLA-linked disease genes has been investigated in a number of studies (Cudworth and Woodrow, 1975; Bobrow et al., 1975; Day and Simons, 1976; Thomson and Bodmer, 1979a, b; Green and Woodrow, 1977; Suarez, 1978; Spielman et al., 1978, 1979, and 1980). It is based on the assumption that HLA haplotypes as marker are used to trace the inheritance pattern of closely linked disease susceptibility genes. Looking at families in which two or more siblings had disease in question, the nonrandom zygotic assortment of HLA haplotypes would be a demonstration of disease gene.

Let us suppose that HLA haplotypes of both parents are $a / b$ and $c / d$. Genotypes of their children will be either $a / c$ or $a / d$ or $b / c$ or $b / d$. Since each genotype happens to appear independently, the probabilities that two siblings share two, one or no haplotypes identical by descent are $1 / 4,1 / 2$ and $1 / 4$, respectively. These are in fact the k-coefficient (Cotterman, 1940) or $k_{2}, k_{1}$ and $k_{0}$ in his terminology, in which neither of individuals was inbred.

To facilitate counting the value of $\mathrm{X}, \mathrm{Y}$ and $\mathrm{Z}$, respectively the number of affected sib pairs, ascertained through sibs, sharing two, one or no haplotypes, with information about parental genotypes only, the marker locus must carry at least four distinctive alleles or haplotypes. In other words, there must be four distinct haplotypes in parents in order to identify siblings sharing two, one or no haplotypes identical by descent. It can be shown that the probability of both parents being distinct heterozygotes is $(1-1 / \mathrm{m})(1-2 / \mathrm{m})(1-3 / \mathrm{m})$ provided that frequencies of all alleles are the same, where $m$ is the number of alleles at the marker locus. As shown in Fig. 1, it is understandable that HLA system having a many haplotypes is a good candidate as a marker. This will be discussed later.

Fishman et al. (1978) have studied the expected number of $X, Y$ and $Z$ under the hypothesis of recessives as well as dominants at the disease locus. The recessive case yields

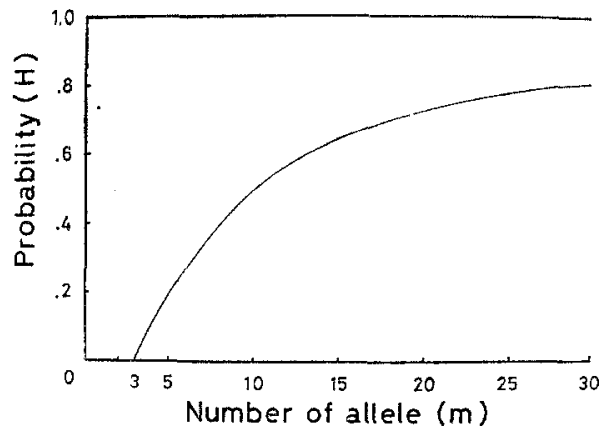

Fig. 1. The probability of both parents being distinctive heterozygotes in random mating population: $H=\Sigma\left(2 p_{1} p_{j}\right)\left(2 p_{k} p_{1}\right)=(1-1 / m)(1-2 / m)(1-3 / m)$ for $p_{1}=1 / m$, where $\mathrm{m}$ is the number of allele. 


$$
\begin{aligned}
& E_{r}(X)=N[p+\phi(1-p)]^{2} /(1+p)^{2} \\
& E_{r}(Y)=N[2 p+2 \phi(1-\phi)(1-p)]^{2} /(1+p)^{2} \quad \text { and } \\
& E_{r}(Z)=N[\phi p+(1-\phi)]^{2} /(1+p)^{2}
\end{aligned}
$$

Dominant hypothesis leads to

$$
\begin{aligned}
& E_{d}(X)=N\left[p(1+q)^{2}+\phi q^{2}(2 q+\phi p)\right] /\left[4(1+p q)+p q^{2}\right], \\
& E_{d}(Y)=N\left[2+2 p q+2 \phi(1-\phi) q^{2} p\right] /\left[4(1+p q)+p q^{2}\right] \\
& E_{d}(Z)=N\left[1+q-\phi q^{2}(2-\phi p)\right] /\left[4(1+p q)+p q^{2}\right]
\end{aligned} \text { and }
$$

in which $E(\cdot)$ denotes the expectation, $N$ is the observed number of affected sib pairs, $p$ is the frequency of disease gene, $q=1-p$ and $\phi=(1-c)^{2}+c^{2}$ with $c$ being recombination frequency between marker and disease loci. Table $1 \mathrm{a}$ and $1 \mathrm{~b}$ give respectively the values of $\mathrm{E}(\cdot)$ for recessive and dominant models, with $\mathrm{p}$ from 0 . to 1. with the increment 0.05 and $c$ from 0 . to 0.05 with the increment 0.01 and $c=0.1$, $0.2,0.3$ and 0.4 , assuming $N=100$. As observed in Table $1 \mathrm{~b}$, the expected number of sib pairs sharing one haplotype in dominant model or $E_{d}(Y)$ is nearly always 50 . for all examined values of $p$ and $c$. In recessive model on the other hand $E_{r}(Y)$ 's are much smaller than 50. when p's are less than, say, 0.5. Discrimination between the two models could be made effectively using an index $X / Z$ for small value of $p$. The index is much higher in the recessive model than in the dominant one. More specifically, we search the minimum value of a quantity

$$
\chi^{2}=\sum_{i=X, Y, Z} \frac{\left[E_{d}(i)-E_{x}(i)\right]^{2}}{E_{r}(i)}
$$

for a given gene frequency in the recessive model which has taken as the expectation. By examining gene frequency in the dominant model, the minimum value of chisquare could be found, where $E_{d}(i)$ 's are reckoned as the 'observation.' Discrimination between the two models would not be made if frequency of recessive gene was higher than 0.4 and/or that of dominant gene was higher than 0.1 even the sample size of sib pairs being one hundred. In other words the affected sib pair method seems not to be applicable effectively to common disease (Table 2).

When $\mathrm{p}$ is small, the expectations approach to

$$
\begin{array}{lll}
E_{r}(X)=N(1-2 p), & & E_{d}(X)=N(0.5-0.875 p), \\
E_{r}(Y)=N(2 p), & & E_{d}(Y)=N(0.5-0.125 p), \\
E_{r}(Z)=0 & & E_{d}(Z)=N p .
\end{array}
$$

The effect of recombination could be observed by the following approximation when $\mathrm{c}$ goes to nearly zero or $\mathrm{c} \rightarrow 0$. For the recessive model 


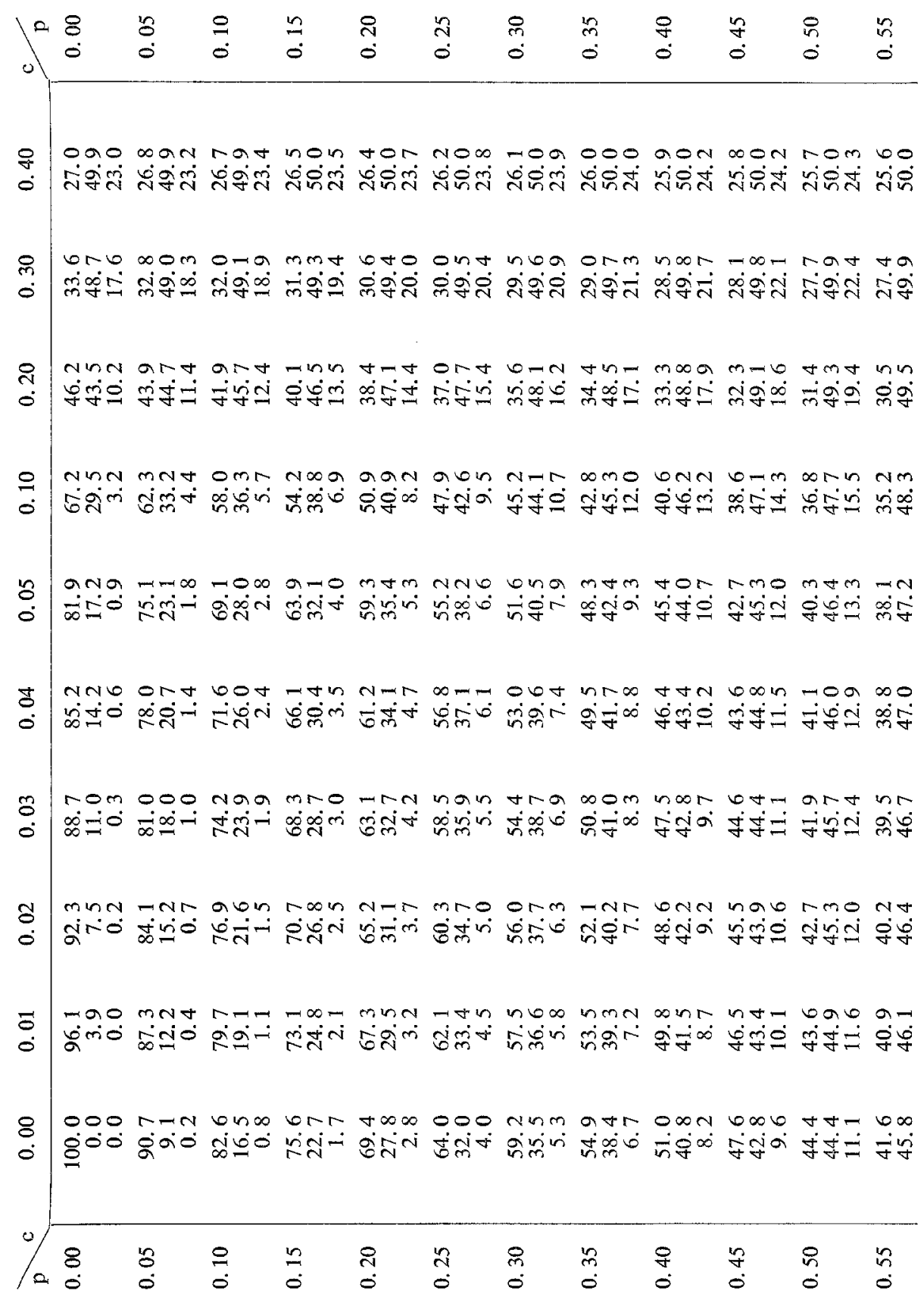




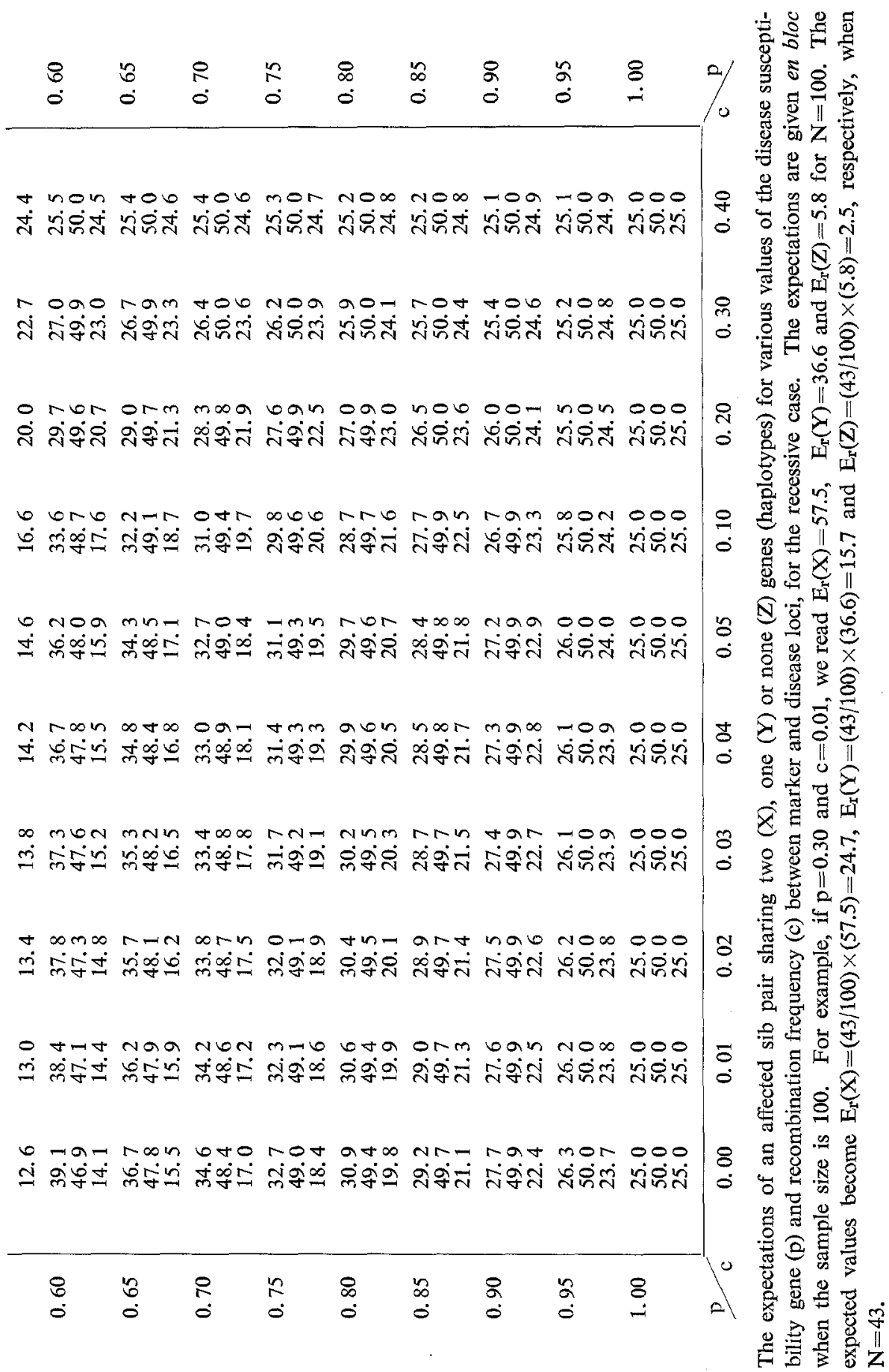




\begin{tabular}{|c|c|c|c|c|c|c|c|c|c|c|c|}
\hline$=\begin{array}{l}8 \\
0\end{array}$ & $\stackrel{8}{0}$ & $\stackrel{0}{0}$ & $\frac{n}{0}$ & $\stackrel{\text { ஸे }}{0}$ & $\stackrel{1}{2}$ & 官 & $\begin{array}{l}n \\
m \\
0\end{array}$ & $\begin{array}{l}8 \\
0 \\
0\end{array}$ & $\stackrel{n}{\circ}$ & $\stackrel{n}{0}$ & $\stackrel{n}{n}$ \\
\hline 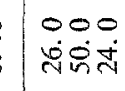 & $\begin{array}{l}\text { mon } \\
\text { mind }\end{array}$ & $\begin{array}{l}\text { nom } \\
\text { ñind }\end{array}$ & $\begin{array}{l}\text { bot } \\
\text { भi̊nं }\end{array}$ & 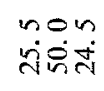 & 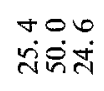 & $\begin{array}{l}\text { mor } \\
\text { visind }\end{array}$ & $\begin{array}{l}\text { mor } \\
\text { nंघंते }\end{array}$ & 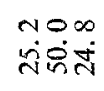 & 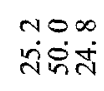 & 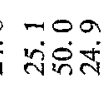 & 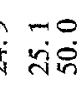 \\
\hline $\begin{array}{l}000 \\
\text { ปूंहिंत }\end{array}$ & $\begin{array}{l}\text { mon } \\
\text { disiñ }\end{array}$ & 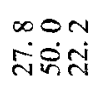 & $\begin{array}{l}\text { mor } \\
\text { तेंिंत }\end{array}$ & 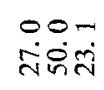 & 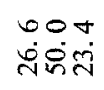 & 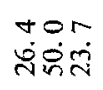 & 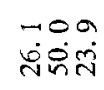 & 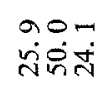 & 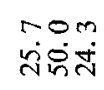 & $\begin{array}{l}00 \pi \\
\text { भंष्में }\end{array}$ & 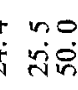 \\
\hline $\begin{array}{l}000 \\
\text { min }\end{array}$ & $\begin{array}{l}\ln 90 \\
\text { migi }\end{array}$ & $\begin{array}{l}m a \infty \\
\dot{m} \dot{q}+\infty\end{array}$ & $\begin{array}{l}m \infty a \\
\dot{m} \dot{g}\end{array}$ & $\begin{array}{l}+\infty \\
\dot{\lambda} \dot{\theta} \dot{\hat{N}}\end{array}$ & $\begin{array}{l}r \infty n \\
\ddot{\sim} \dot{q} \bar{\sim}\end{array}$ & 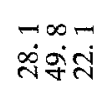 & 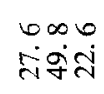 & 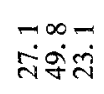 & $\begin{array}{l}\sim \infty \\
\dot{\delta} \sigma \dot{\theta}\end{array}$ & $\begin{array}{l}+\infty \infty \\
\dot{s i g} \\
\text { is }\end{array}$ & : \\
\hline $\begin{array}{l}000 \\
\dot{\nabla}: \dot{n}^{\circ}\end{array}$ & $\begin{array}{l}+\infty \infty \\
\infty \dot{m} \sigma=\end{array}$ & $\begin{array}{l}m 0- \\
\dot{\varphi g g} t\end{array}$ & $\begin{array}{l}\text { mino } \\
\text { म̇go }\end{array}$ & $\begin{array}{l}\text { onn } \\
\text { migiv }\end{array}$ & $\begin{array}{l}\because+\infty \\
\dot{m} \dot{\sigma} \infty\end{array}$ & $\begin{array}{l}0+0 \\
\dot{m} \dot{\theta} \dot{8}\end{array}$ & 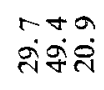 & 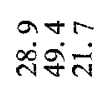 & $\begin{array}{l}\text { Ninm } \\
\text { oigi }\end{array}$ & $\begin{array}{l}\ln a \\
\text { กิ\%ं }\end{array}$ & ते \\
\hline 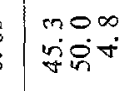 & $\begin{array}{l}\text { orm } \\
\dot{j} \dot{g} \infty\end{array}$ & $\begin{array}{l}m \sigma m \\
\dot{m} \dot{y}=\end{array}$ & mivi & nisin & $\begin{array}{l}\dot{m}= \\
\dot{m g}=\end{array}$ & $\begin{array}{l}\text { Nor } \\
\text { njås }\end{array}$ & $\begin{array}{l}\text { ma } \\
\dot{m} \dot{\theta} \dot{0}\end{array}$ & 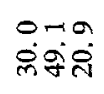 & वंभें & 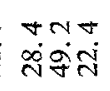 & ते \\
\hline $\begin{array}{l}\text { Nom } \\
\text { ifin }\end{array}$ & $\begin{array}{l}\infty 00 \\
\text { jog. } \\
\text { jơ }\end{array}$ & $\begin{array}{l}\text { ont } \\
\text { gigo }\end{array}$ & $\begin{array}{l}\text { MNY } \\
\ddot{m} g i m\end{array}$ & $\begin{array}{l}\text { nom } \\
\text { nigiv }\end{array}$ & $\begin{array}{l}000 \\
\dot{m} \dot{0}=\end{array}$ & $\begin{array}{l}b a n \\
\dot{i \infty} \infty \\
m \stackrel{\infty}{=}\end{array}$ & $\begin{array}{l}\text { yor } \\
\dot{m i g} \dot{0}\end{array}$ & $\begin{array}{l}\text { mor } \\
\dot{m} \dot{\theta} \dot{\theta} \dot{8}\end{array}$ & $\begin{array}{l}\text { moo } \\
\text { inaं }\end{array}$ & $\begin{array}{l}n=m \\
\infty \\
\infty\end{array}$ & $\left\{\begin{array}{l}\infty \\
\dot{N}\end{array}\right.$ \\
\hline $\begin{array}{l}-00 \\
\dot{\sigma} \dot{8} \vec{~}\end{array}$ & $\begin{array}{l}0, \infty \\
\dot{\gamma} \dot{q} \dot{\sigma}\end{array}$ & $\begin{array}{l}\text { rmo } \\
\dot{q} \dot{q} \dot{\theta}=\end{array}$ & moja & $\begin{array}{l}\text { Nom } \\
\text { i̊gad }\end{array}$ & $\begin{array}{l}\text { nar } \\
\dot{m} \dot{\phi} \phi \dot{0}\end{array}$ & $\begin{array}{l}\infty \infty N \\
\dot{m} \dot{\infty} \infty \\
\dot{m} \dot{\infty}\end{array}$ & $\begin{array}{l}n g n \\
\dot{m} \dot{y} \sigma\end{array}$ & $\begin{array}{l}\text { now } \\
\dot{m} \dot{\infty} \dot{\phi}\end{array}$ & $\begin{array}{l}\text { bon } \\
\text { बigan }\end{array}$ & 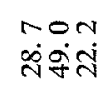 & 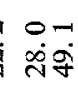 \\
\hline $\begin{array}{l}000 \\
\text { pogini }\end{array}$ & $\begin{array}{l}+n-1 \\
\dot{\forall} g \dot{\sigma}\end{array}$ & $\begin{array}{l}\forall N \sigma \\
\dot{\nabla} \sigma a\end{array}$ & $\begin{array}{l}\infty \circ N \\
\infty \sigma i v \\
m i d\end{array}$ & $\begin{array}{l}\text { Nav } \\
\dot{D} \dot{\infty} \pm\end{array}$ & 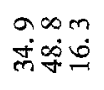 & $\begin{array}{l}m r a \\
m \dot{m}\end{array}$ & $\begin{array}{l}0 \infty m \\
\text { ijos } \\
\text { nisa }\end{array}$ & $\begin{array}{l}\infty \infty \pi \\
\dot{\bar{m}} \dot{\infty} \dot{\sigma}\end{array}$ & $\begin{array}{l}\infty a m \\
\text { ìंकें }\end{array}$ & $\begin{array}{l}90- \\
\dot{i} \dot{\sigma} \dot{\gamma}\end{array}$ & 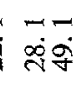 \\
\hline $\begin{array}{l}000 \\
\text { gis }\end{array}$ & $\begin{array}{l}\text { Ninm } \\
\text { vigin }\end{array}$ & $\begin{array}{l}-N \infty \\
\dot{q} \dot{q}^{\prime} \infty\end{array}$ & 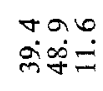 & 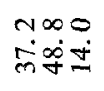 & $\begin{array}{l}m n o \\
\text { miso }\end{array}$ & miñ & $\begin{array}{l}m r \\
\text { miso }\end{array}$ & MNo & $\begin{array}{l}0 \infty N \\
\dot{m} \dot{\infty} \dot{+}\end{array}$ & $\begin{array}{l}-90 \\
\text { i⿱宀⿻心㇒ }\end{array}$ & 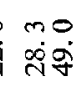 \\
\hline $\begin{array}{l}000 \\
\text { inin: }\end{array}$ & $\begin{array}{l}\text { onin } \\
\dot{g} g \operatorname{tr}\end{array}$ & 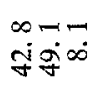 & $\begin{array}{l}-\infty= \\
\dot{q}+\infty\end{array}$ & $\begin{array}{l}\infty 10 \\
\dot{m} \dot{\phi}=\end{array}$ & $\begin{array}{l}\text { obr } \\
\text { risos }\end{array}$ & 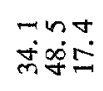 & 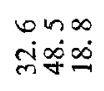 & $\begin{array}{l}m b- \\
\dot{m} \dot{\infty} \dot{8}\end{array}$ & 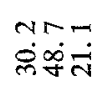 & $\begin{array}{l}m \infty 0 \\
\text { iి }\end{array}$ & $\begin{array}{l}+\infty \\
\infty \\
\sim\end{array}$ \\
\hline $\begin{array}{l}8 \\
0\end{array}$ & $\begin{array}{l}\stackrel{2}{0} \\
0\end{array}$ & $\stackrel{\circ}{\circ}$ & $\frac{n}{0}$ & $\begin{array}{l}\text { ָิ } \\
0\end{array}$ & $\stackrel{\sim}{\circ}$ & ্ֻలি & $\stackrel{n}{0}$ & $\begin{array}{l}\text { o } \\
0\end{array}$ & $\stackrel{\text { fo }}{0}$ & $\stackrel{n}{\circ}$ & 吴 \\
\hline
\end{tabular}




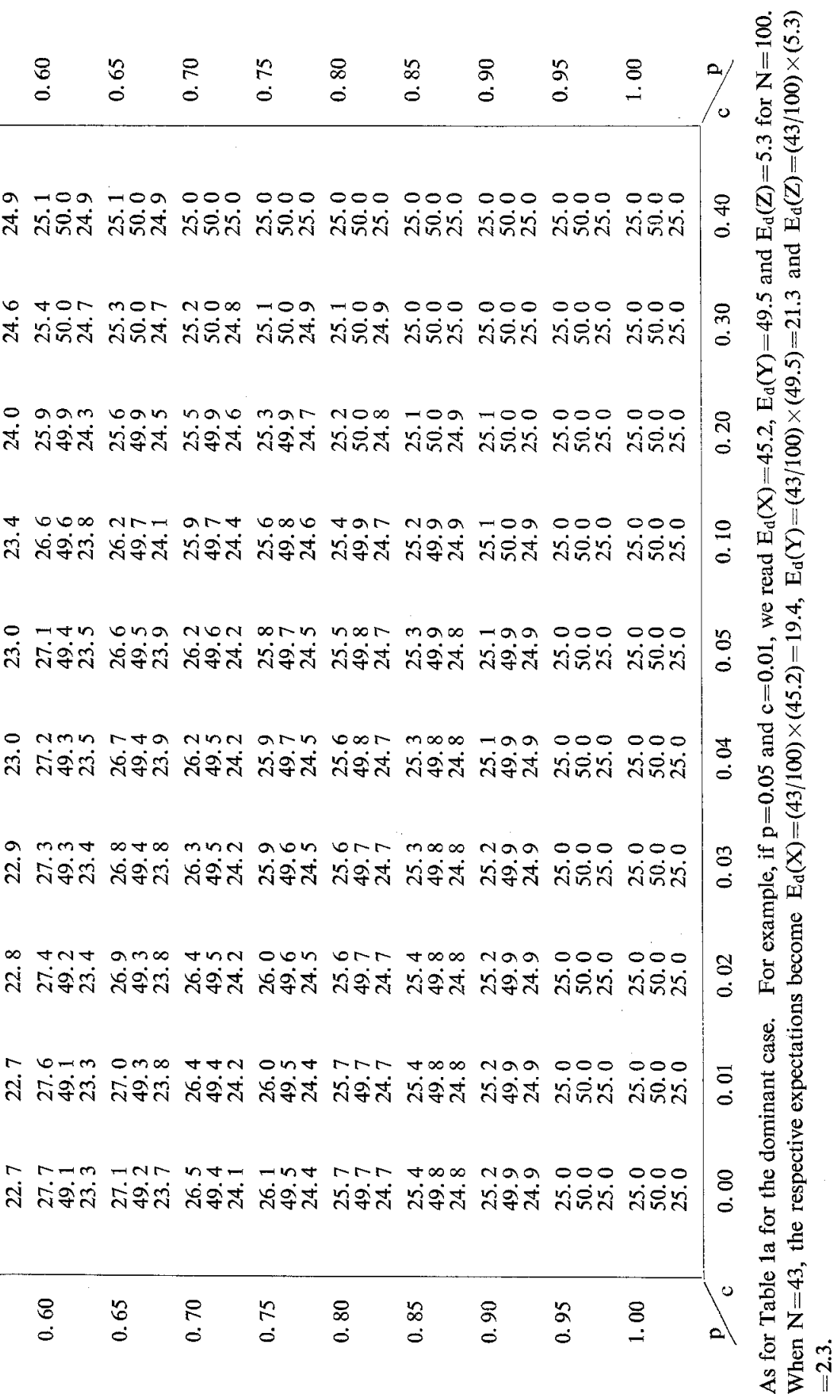

Vol. 27, No. 4, 1982 
Table 2.

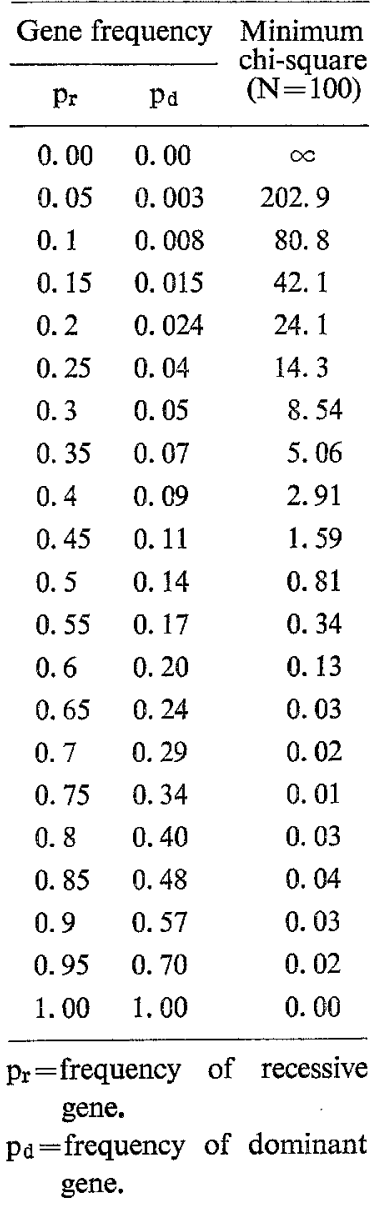

Table 3. Subsidary table for computation of $\mathrm{U}$ and $\mathrm{K}$ scores.

\begin{tabular}{ccccccc}
\hline $\mathrm{p}$ & $\mathrm{C}(\mathrm{X})$ & $\mathrm{C}(\mathrm{Y})$ & $\mathrm{C}(\mathrm{Z})$ & $\mathrm{K}$ (Dom) & $\mathrm{K}(\mathrm{Res})$ & $\mathrm{p}$ \\
\hline 0.00 & -1.7500 & -0.2500 & $\infty$ & $\infty$ & $\infty$ & 0.00 \\
0.01 & -1.7077 & -0.2348 & 97.7897 & 94.9801 & 199.9803 & 0.01 \\
0.02 & -1.6670 & -0.2204 & 47.8279 & 45.1386 & 99.9615 & 0.02 \\
0.03 & -1.6277 & -0.2067 & 31.1979 & 29.6220 & 66.6101 & 0.03 \\
0.04 & -1.5899 & -0.1938 & 22.8998 & 20.4308 & 49.9260 & 0.04 \\
0.05 & -1.5535 & -0.1815 & 17.9336 & 15.5656 & 39.9093 & 0.05 \\
0.06 & -1.5183 & -0.1698 & 14.6328 & 12.3603 & 33.2265 & 0.06 \\
0.07 & -1.4842 & -0.1587 & 12.2832 & 10.1011 & 28.4491 & 0.07 \\
0.08 & -1.4513 & -0.1481 & 10.5277 & 8.4312 & 24.8628 & 0.08 \\
0.09 & -1.4195 & -0.1380 & 9.1679 & 7.1526 & 22.0707 & 0.09 \\
0.10 & -1.3887 & -0.1284 & 8.0849 & 6.1467 & 19.8347 & 0.10 \\
0.11 & -1.3588 & -0.1193 & 7.2029 & 5.3379 & 18.0032 & 0.11 \\
0.12 & -1.3299 & -0.1105 & 6.4715 & 4.6762 & 16.4753 & 0.12 \\
0.13 & -1.3018 & -0.1022 & 5.8557 & 4.1268 & 15.1810 & 0.13 \\
0.14 & -1.2745 & -0.0942 & 5.3306 & 3.2727 & 14.0702 & 0.14 \\
0.15 & -1.2480 & -0.0866 & 4.8780 & 3.2727 & 13.1064 & 0.15 \\
0.16 & -1.2222 & -0.0793 & 4.4842 & 2.9364 & 12.2621 & 0.16 \\
0.17 & -1.1972 & -0.0724 & 4.1386 & 2.6458 & 11.5163 & 0.17 \\
0.18 & -1.1728 & -0.0657 & 3.8332 & 2.3929 & 10.8525 & 0.18 \\
0.19 & -1.1491 & -0.0593 & 3.5615 & 2.1715 & 10.2579 & 0.19 \\
0.20 & -1.1260 & -0.0532 & 3.3184 & 1.9766 & 9.7222 & 0.20 \\
0.25 & -1.0187 & -0.0262 & 2.4098 & 1.2808 & 7.6800 & 0.25 \\
0.30 & -0.9231 & -0.0042 & 1.8219 & 0.8676 & 6.3116 & 0.30 \\
0.40 & -0.7582 & 0.0280 & 1.1167 & 0.4308 & 4.5918 & 0.40 \\
0.50 & -0.6178 & 0.0487 & 0.7154 & 0.2252 & 3.5555 & 0.50 \\
0.60 & -0.4927 & 0.0602 & 0.4596 & 0.1181 & 2.8645 & 0.60 \\
0.70 & -0.3755 & 0.0630 & 0.2837 & 0.0587 & 2.3727 & 0.70 \\
0.80 & -0.2597 & 0.0563 & 0.1569 & 0.0249 & 2.0061 & 0.80 \\
0.90 & -0.1377 & 0.0374 & 0.0642 & 0.0065 & 1.7236 & 0.90 \\
1.00 & 0.0000 & 0.0000 & 0.0000 & 0.0000 & 1.5000 & 1.00 \\
\hline
\end{tabular}

$\mathrm{p}=$ gene frequency.

$$
\begin{aligned}
& E_{r}(X)=N\left[1 /(1+p)^{2}-\left\{4 q /(1+p)^{2}\right\} c\right], \\
& E_{r}(Y)=N\left[2 p /(1+p)^{2}+\left\{4 q^{2} /(1+p)^{2}\right\} c\right] \quad \text { and } \\
& E_{r}(Z)=N\left[p^{2} /(1+p)^{2}+\left\{4 p q /(1+p)^{2} c\right] .\right\}
\end{aligned}
$$

For the dominant model

$$
\begin{aligned}
& E_{d}(X)=N\left[(1+q) / R-\left\{4 q^{2} / R\right\} c\right], \\
& E_{d}(Y)=N\left[2 p(1+p)^{2} / R+\left\{4 q^{2} p / R\right\} c\right] \quad \text { and } \quad E_{d}(Z)=N\left[p(1+q)^{2} / R+\left\{4 q^{3} / R\right\} c\right]
\end{aligned}
$$


in which $R=4(1+p q)+p^{2}$.

Thus the primary effect of recombination frequency on $E(\cdot)$ is to reduce $E(X)$ or frequency of sib pair sharing two haplotypes identical by descent in either model, and to increase proportionally $E_{\mathbf{r}}(Y)$ and/or $E_{\mathrm{d}}(Y)$.

\section{MAXIMUM LIKELIHOOD ESTIMATION}

Since our interest is primarily directed to the case where there is no recombination $(\mathrm{c}=0)$ between marker and disease loci, the following result would be useful for obtaining maximum likelihood solution. General treatments when recombination frequency was not necessarily zero were given in appendix.

Recessive model. Maximum likelihood solution of disease gene frequency $p$ and variance $V(p)$ will be

$$
\hat{\mathrm{p}}=\frac{\mathrm{Y}+2 Z}{\mathrm{Y}+2 \mathrm{X}} \quad \text { and } \quad \mathrm{V}(\hat{\mathrm{p}})=\frac{\mathrm{p}(1+\mathrm{p})^{2}}{2 \mathrm{~N}(1+2 \mathrm{p})}, \text { respectively. }
$$

The reciprocal of variance is called the amount of information or

$$
\frac{\mathrm{K}(\mathrm{Res})}{\mathrm{N}}=\frac{1}{\mathrm{NV}(\hat{\mathrm{p}})}=\frac{2(1+2 \mathrm{p})}{\mathrm{p}(1+\mathrm{p})^{2}} \rightarrow \frac{2}{\mathrm{p}} \text { as } \mathrm{p} \rightarrow 0,
$$

of which values are given in the 6th column in Table 3 for some $\mathrm{p}$.

Dominant model. Analytical solution may not be feasible so that iterative method must be employed. With a trial value of $\mathrm{p}_{0}$, the iterative process would be proceeded by

in which

$$
\hat{\mathrm{p}}=\mathrm{p}_{0}+[\mathrm{U} / \mathrm{K}]_{0},
$$

$$
\mathrm{U}=\mathrm{C}(\mathrm{X}) \mathrm{X}+\mathrm{C}(\mathrm{Y}) \mathrm{Y}+\mathrm{C}(\mathrm{Z}) \mathrm{Z}
$$

and

$$
K=\frac{2 N q^{2}\left[6(1+q)+q^{2}(1+p)(4+p)\right]}{p(1+q)(1+p q)\left[4(1+p q)+p q^{2}\right]^{2}}
$$

where

$$
C(X)=\frac{-2 q\left(3+3 q+q^{2}\right)}{(1+q)\left[4(1+p q)+p q^{2}\right]}, \quad C(Y)=\frac{q[2 p-q(1+p)]}{(1+p q)\left[4(1+p q)+p q^{2}\right]}
$$

and

$$
C(Z)=\frac{2 q\left(1+4 q-q^{3}\right)}{p(1+q)\left[4(1+p q)+p q^{2}\right]} . \quad \text { Also, }[\cdot]_{0} \text { designates }
$$

the value inside brackets computed with $\mathrm{p}_{0}$.

The amount of information in dominant model approaches to $\mathrm{K}(\mathrm{Dom})=\mathrm{K} / \mathrm{N} \rightarrow$ 
$2 / \mathrm{p}$ as $\mathrm{p} \rightarrow 0$. For computational convenience all C's and $\mathrm{K}(\mathrm{Dom})$ are tabulated for some values of $\mathrm{p}$ (Table 3 ). If disease gene frequency was small as is usual the case, it might be taken $\mathrm{p}_{0}=4 \mathrm{Z} /(7 \mathrm{X}+\mathrm{Y}+8 \mathrm{Z})$ or an arbitrary value 0.01 as trial estimate. It is of statistically interest to note that the amount of information becomes the same $(2 / p)$ in both models when frequency of the disease gene becomes zero.

\section{GRAVES' DISEASE AS AN ILLUSTRATIVE EXAMPLE}

Graves' disease has been considered a multifactorial disease. Although the genetic mechanism involved in its manifestation is yet unknown, it has been reported that there were statistical associations between Graves' disease and HLA as well as Gm loci (Uno et al., 1981). In that study examination of HLA haplotypes of 15 affected sib pairs who were ascertained through one of sibs (single ascertainment) and whose parents had four distinct HLA haplotypes, yielded the distribution $X=8, Y=7$ and $Z=0$. If assortment of HLA haplotype was at random, the expected distribution would be $3.75: 7.50: 3.75$. The value of chi squared for a goodness of fit becomes $\chi^{2}=8.60$ with two degrees of freedom, which is significant $(\mathrm{P}=$ 0.014) (Table 4).

Under the recessive hypothesis the maximum likelihood solution was $\hat{p}=$ $(7+2 \cdot 0) /(7+2 \cdot 8)=0.30$ with the variance $V(\hat{\mathrm{p}})=1 /[(15)(6.3116)]$ (from Table 3$)=$ $(0.10)^{2}$ yielding $\chi^{2}=1.39$ with one degree of freedom for goodness of fit that is not significant (Table 4). For dominant model, we start iterative process with $\mathrm{p}_{0}=0.01$. The scores are then

$\mathrm{U}=(-1.7077)(8)+(-0.2348)(7)+(97.7898)(0)=-15.3052$ and $\mathrm{K}=(15)(94.9801)=$ $1,424.7015$ so that $[\mathrm{U} / \mathrm{K}]_{0}=-0.01$ (Numerical values are found from Table 3 ). Thus, maximum likelihood solution becomes $\hat{\mathrm{p}}=0$, giving $\chi^{2}=0.07$ with one degree of freedom, that is insignificant.

Since the frequency 0.00 for disease gene did not make sense, we could get

Table 4. Tests of genetic hypothesis on Graves' disease based on HLA haplotype assortment data.

\begin{tabular}{|c|c|c|c|c|c|c|c|}
\hline \multicolumn{2}{|c|}{$\begin{array}{l}\text { Two affected sibs shared } \\
\text { haplotypes }\end{array}$} & \multicolumn{2}{|c|}{$\begin{array}{l}\text { Recessive } \\
\operatorname{ex}^{a}\left(\chi^{2}\right)\end{array}$} & \multicolumn{2}{|c|}{$\begin{array}{l}\text { Dominant } \\
\operatorname{ex}^{b}\left(\chi^{2}\right)\end{array}$} & \multicolumn{2}{|c|}{$\begin{array}{l}\text { Random } \\
\operatorname{exc}\left(\chi^{2}\right)\end{array}$} \\
\hline Two $(X=0.533)$ & 8 & 8.82 & $(0.08)$ & 7.50 & $(0.03)$ & 3.75 & $(4.82)$ \\
\hline One $\quad(Y=0.467)$ & 7 & 5.37 & $(0.50)$ & 7.50 & $(0.03)$ & 7.50 & $(0.03)$ \\
\hline None $(\mathrm{Z}=0)$. & 0 & 0.82 & $(0.82)$ & 0.00 & $(0.00)$ & 3.75 & $(3.75)$ \\
\hline Total & 15 & & $(1.39)$ & & $(0.07)$ & & $(8.60)^{*}$ \\
\hline
\end{tabular}

$* 0.01<\mathrm{p}<0.025$.

a Based on the estimated gene frequency $0.30 \pm 0.10$.

b Based on gene frequency 0.00 obtained by maximum likelihood.

c Based on random ratio $1: 2: 1$. 
appreciable gene frequency $(0.08)$ under the dominant model at $\chi^{2}=1.34$, which is comparable to the chi squared for the recessive model. At this stage with a small size of the sample $(\mathrm{N}=15)$, it is not possible to rule out the dominant model simply because the maximum likelihood estimate of the gene frequency being 0.00 . Since this affected sib pair method was based on the assumption of no recombination between HLA and the disease loci, the real gene frequency should be smaller if we take into account of the crossover between two loci (appendix). The recessive gene frequencies estimated for a given recombination fraction (c) decreased from $0.304 \pm$ 0.104 to $0.206 \pm 0.099$ at the recombination frequency 0.00 to 0.05 , respectively. This decrease however is within the standard error.

It is possible, assuming high penetrance of Graves' disease, to infer the mode of inheritance and frequency of Gm-linked disease gene by utilizing both the estimated frequency of the Gm-linked disease gene and the observed incidence of Graves' disease in the Japanese population $(8 / 10,000)$ (Maruchi et al., 1969). Suppose that $p_{1}$ is the frequency of the HLA-linked gene, $p_{2}$ is the frequency of the Gm-linked gene, $\mathrm{x}$ is penetrance of the genotype for Graves' disease. The expected frequency of affected individuals is the $\mathrm{xp}_{1}{ }^{2} \mathrm{p}_{2}{ }^{2}$ based on the recessive model for the Gm-linked gene as well as HLA-linked gene. With $p_{1}=0.30$ and computing various values for

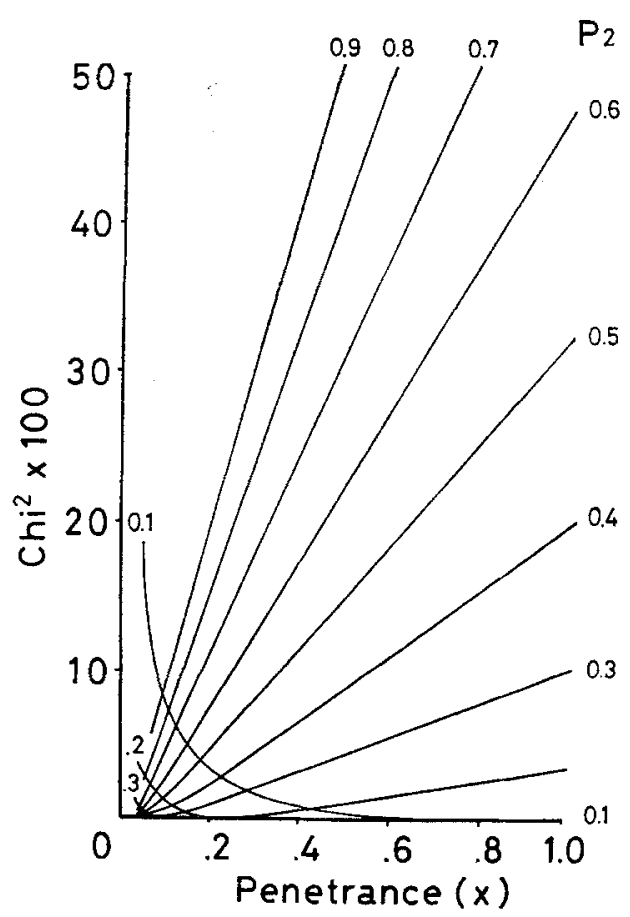

Fig. 2. A goodness of fit to two locus model, where $\mathrm{p}_{2}$ is a gene frequency at the Gmlinked locus. Both loci were assumed to be recessive. Note that the values of chi-square are minimum when $p_{2}=0.10$ and $0.60<x<1.00$ where $x$ is penetrance. 


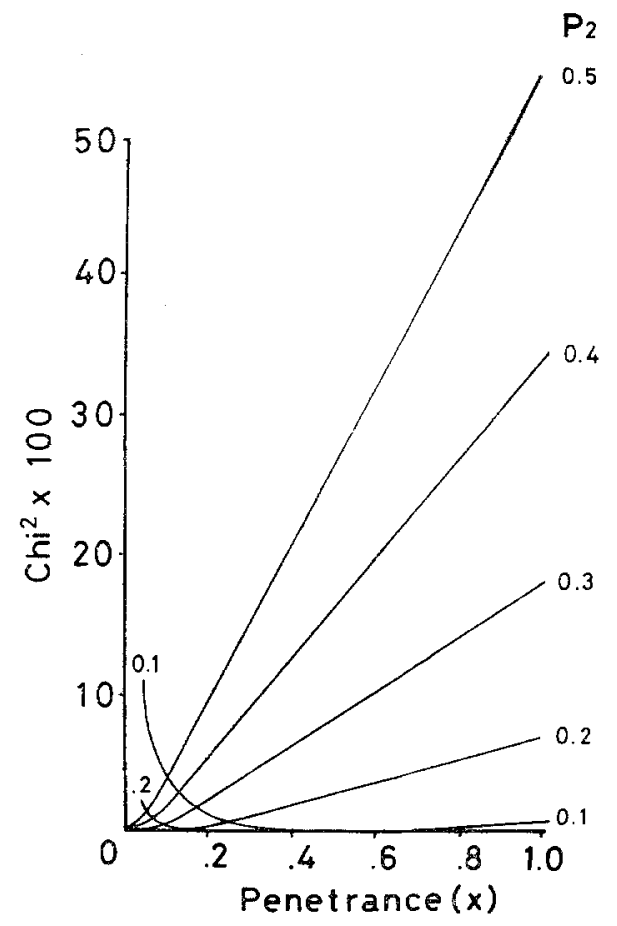

Fig. 3. A goodness of fit to two locus model, where $\mathrm{p}_{2}$ is a gene frequency at the Gmlinked locus. The HLA-linked locus was assumed to be dominant and the Gm-linked locus recessive. Note that the values of chi-square are minimum when $\mathrm{p}_{2}=0.10,0.5<\mathrm{x}<1.0$.

$\mathrm{p}_{2}$ and $\mathrm{x}$, from 0 . to 1 ., we found minimum chi squared for $\mathrm{p}_{2}=0.10$ and $0.60<\mathrm{x}<1.00$ (Fig. 2). No compatible figures could be found for $x$ and $p_{2}$ with dominant hypothesis at the Gm-linked locus. Under the dominant model for the HLA-linked locus with $\mathrm{p}_{1}=0.08$ and the recessive model for the Gm-linked locus, where the expected incidence of affected individuals is approximately $2 \mathrm{xp}_{1} \mathrm{p}_{2}{ }^{2}$, it appears that $\mathrm{p}_{2}=0.1$ and $0.5<\mathrm{x}<1.0$ (Fig. 3). In this case the second locus as a dominant one was not compatible with the present data.

\section{DISCUSSION}

This affected sib pair analysis clearly indicated that two major genes, linked to HLA and Gm, respectively, control the susceptibility to Graves' disease as previously reported (Uno et al., 1981 and Sasazuki et al., 1981). For the HLA-linked disease susceptibility gene, the observed distortion in the distribution of affected sib pairs sharing two, one or no haplotypes identical by descent could not clearly distinguish the recessive model with gene frequency of 0.30 from the dominant model with gene 
frequency of 0.01 . Since the dominant model yielded the gene frequency being 0.00 as a maximum likelihood solution, the recessive model was more tenable. This difficulty is in part due probably to the smallness of sample size in this study, and analysis of much larger number of affected sib pairs might be necessary to exclude either the dominant or recessive model. In fact a compilation of literature (Sasazuki, unpublished) resulted a distribution $X=27, Y=14$, and $Z=2$ (so that $N=43$ ), which yielded recessive gene frequency $0.26 \pm 0.06$ with $\chi^{2}=0.01$ and dominant gene frequency $0.04 \pm 0.03$ with $\chi^{2}=4.98$. Namely, dominant hypothesis for HLA-linked gene may be excluded, but definite conclusion must await a carefully designed survey for segregation analysis as well as linkage study of Graves' disease and HLA/Gm.

The above analysis suggests an answer to a question that how many sib pairs are necessary to discriminate two hypotheses between recessives and dominants. The size of sample is obviously dependent upon frequency of disease gene. Having recessive gene frequency of 0.25 and sample size of 15 , the minimum chi squared to discriminate two models is $(15 / 100) \times(14.3)=2.15$ (Table 2 ), that is certainly not significant. When $\mathrm{N}=43$, the minimum $\chi^{2}=(43 / 100) \times(14.3)=6.15$ which is now significant at $5 \%$ level. A typical size taking into account conventional cases would be at least 20 or 30 .

In the recessive model for the HLA-linked disease gene, the minimum gene frequency of 0.30 would correspond to a minimum frequency of $(0.30)^{2}=0.09$ of homozygotes in the population, and since the incidence of Graves' disease in the Japanese population is 0.0008 , penetrance $(x)$ of these homozygotes would be at least 0.0008 / 0.09 or $0.9 \%$ which might suggest either multifactorial or a single major locus. In the present data however there was a second locus linked to $\mathrm{Gm}$ so that we did not discard the recessive model because of too low penetrance. Two locus model for Graves' disease was thus shown by the demonstration of tightly linked loci, HLA and $\mathrm{Gm}$.

When an association between marker locus and disease was found by using $2 \times 2$ contingency table (Woolf, 1955), investigation could go to gather affected sib pairs whose genetic markers were examined. Since parental genotypes of affected sibs could easily be examined or be deduced from phenotypes of children and surviving spouse, marker system is preferable to contain multiple codominant alleles. Nearly all blood groups in man do not meet the condition, but only exception at present in HLA system (Table 5). Rh blood groups maintain at least eight alleles but some of them are so rare among Japanese that actually observed number of alleles would be reduced. No wonder why ABO-stomach cancer association has not been confirmed by affected sib pair method while the method has developed solely in study of HLA-disease association. Combination of five markers in HLA will produce enormous number of HLA haplotypes. Although all possible combinations of five markers obviously do not exist in human populations, but even a thousandth the number of all possible haplotypes becomes several hundreds which gives the probability of both parents being distinctive heterozygotes as more than 0.98 , provided 
Table 5. The probability $(\mathrm{H})$ that a couple carries four distinct alleles in random mating population, provided all allele frequency being equal.

\begin{tabular}{lcc}
\hline Genetic system & $\mathrm{m}$ & $\mathrm{H}$ \\
\hline $\begin{array}{l}\text { Lewis, P, Diego } \\
\text { ABO, Lutheran, }\end{array}$ & 2 & 0.00 \\
$\quad$ Kell, Duffy, & 3 & 0.00 \\
$\quad$ Kidd, Km & & \\
MNSs, Gm & 4 & 0.09 \\
HLA-C & $7^{*}$ & 0.35 \\
Rh & 8 & 0.41 \\
HLA-DR & $9^{*}$ & 0.59 \\
HLA-A & $15^{*}$ & 0.65 \\
HLA-B & $29^{*}$ & 0.81 \\
\hline
\end{tabular}

* After Yasuda et al., 1979. $\mathrm{m}=$ number of alleles observed frequently among Japanese population.
Table 6. Cotterman's k-coefficient

\begin{tabular}{llll}
\hline \multicolumn{1}{c}{ Relationship } & $\mathrm{k}_{2}$ & \multicolumn{1}{c}{$2 \mathrm{k}_{\mathbf{1}}$} & $\mathrm{k}_{\mathbf{0}}$ \\
\hline Monozygotic twin & 1 & 0 & 0 \\
Parent-offspring & 0 & 1 & 0 \\
Ful sib & $1 / 4$ & $1 / 2$ & $1 / 4$ \\
$\begin{array}{l}\text { Half-sib, grandparent- } \\
\text { offspring, uncle-niece }\end{array}$ & 0 & $1 / 2$ & $1 / 2$ \\
First cousin & 0 & $1 / 4$ & $3 / 4$ \\
First-cousin once removed & 0 & $1 / 8$ & $7 / 8$ \\
Second cousin & 0 & $1 / 16$ & $15 / 16$ \\
Unrelated & 0 & 0 & 1 \\
\hline
\end{tabular}

that frequencies of all alleles are the same and mating is random (Fig. 1). Since most polymorphic genes are not associated with disease, HLA or human leucocyte antigen system is at present the only genetic marker which could be useful in affected sib pair method.

In regard to disease, rare diseases would be studied effectively by the affected sib pair method. Here however the problem is to gather the sample of affected sib pairs. By all means the required size of sample is dependent upon gene frequency, but somewhat 20 or 30 pairs would be a reasonable choice. On the other hand, common diseases with high gene frequency may not be practical to resolve effectively genetic causes by affected sib pair method. Since the affected sib pair method is free from penetrance of disease, a question is left whether its incidence is due to a gene with low frequency but high penetrance or due to a common gene with low penetrance. We propose the former model as a working hypothesis which would be testable for searching major gene(s) in multifactorial diseases. In the case of Graves' disease we were led to two locus model with high penetrance. It should be remembered however that affected sib pair method is based on multiple family cases. Sporadic or isolated cases are not included in the analysis. Since etiological heterogeneity in disease is common, the result obtained by sib pair method could only apply to multiple family cases. Segregation analysis and linkage study are required for corroborating the results by sib pair analysis.

Extension of sib pair method to pair of relatives might not be so feasible in practice that the distribution of two relatives sharing two, one or no haplotypes identical by descent could not be identified clearly without serious attempts in pedigree analysis, including HLA typing. Besides, most of close relationships but sib 
provide statistically only one degree of freedom (Table 6). Association between a marker and a disease in question however may be detected by analysis of affected paired relatives, provided that no attempt made for determining mode of inheritance.

Some of other advantages in this approach have been mentioned by Day and Simons (1976). Briefly, 1) multiple case family studies give a direct estimate of the risk; 2) the problem of choosing the correct control group is completely avoided, as the within family segregation provides its own control; and 3) the problem of racial or geographical heterogeneity in HLA antigens could be avoided as the sharing of haplotypes does not depend on which particular HLA antigen is involved, as illustrated in Graves' disease.

Acknowledgements We wish to thank Mr. Kenjiro Fukuhisa for his technical assistance in running computer programs on ACOS-700S installed in the National Institute of Radiological Sciences.

\section{REFERENCES}

Barnstable, C.J., Jones, E.A., and Bodmer, W.F. 1979. Genetic structure of major histocompatibility regions. Int. Rev. Biochem. 22 (Defense and Recognition IIA): 151-225.

Bobrow, M., Bodmer, J.G., Bodmer, W.F., McDevitt, H.O., Lorber, J., and Swift, P. 1975. The search for a human equivalent of the mouse T-locus-negative results from a study of HLAtypes in spina bifida. Tissue Antigens 5: 234-237.

Bodmer, W.F. 1972. Evolutionary significance of the HL-A system. Nature 237: 139-145.

Bodmer, W.F. and Bodmer, J.G. 1978. Evolution and function of the HLA system. Br. Med. Bull. 34: $309-316$.

Cotterman, C.W. 1940. A calculus for statistico-genetics. Ph.D. Thesis. Ohio State University, Columbus, Ohio; 1974. Also In Genetics and Social Structure, Ballonnoff, P., ed., Dowden, Hutchingon \& Ross Inc., Stroudsburg, Pennsylvania, pp. 157-272.

Cudworth, A.G. and Woodrow, J.C. 1975. Evidence for HLA linked genes in "juvenile" diabetes meilitus. Br. Med. J. 3: 133-135.

Dausset, J. 1981. The major histocompatibility complex in man. Science 213: 1469-1474.

Day, N.E. and Simons, M.J. 1976. Disease susceptibility genes-their identification by multiple case family studies. Tissue Antigens 8: 109-119.

Fishman, P.M., Suarez, B., Hodge, S.E., and Reich, T. 1978. A robust method for the detection of linkage in familial diseases. Am. J. Hum. Genet. 30: 308-321.

Frelinger, J.A. and Schreffer, D.C. 1975. The major histocompatibility complex. In Immunogenetics and Immunodeficiency, Benacerraf, B., ed., Univ. Park Press, Baltimore, pp. 81-116.

Green, J.R. and Woodrow, J.C. 1977. Sibling method for detecting HLA-linked genes in disease. Tissue Antigens 9: 31-35.

Maruchi, N., Furihata, R., and Makiuchi, M. 1969. Epidemiological studies on hyperthyroidism. Endocrinol. Jpn. 16: 191-198.

Sasazuki, T., Uno, H., Yasuda, N., Tamai, H., and Matsumoto, H. 1982. Evidence for HLA-linked and Gm-linked genes in Graves' disease. Proc. Clin. \& Biol. Res., B. Boné-Tamir ed., Alan R. Liss. Inc., New York, 103B: 65-76.

Spielman, R.S., Baker, L., and Zmijewski, C. 1978. Genetics of juvenile diabetes: dosage of susceptibility genes. Diabetes 27 (Suppl, 2): 459.

Spielman, R.S., Baker, L., and Zmijewski, C. 1979. Inheritance of susceptibility to juvenile onset diabetes. In The Genetic Analysis of Common Disease. Applications to Preventive Factors in Coronary Heart Disease, Sing, C.F. and Skornick, M.H., eds., Alan R. Liss, New York, pp. 567585.

Vol. 27, No. 4, 1982 
Spielman, R.S., Baker, L., and Zmijewski, C. 1980. Gene dosage and susceptibility to insulin dependent diabetes. Ann. Hum. Genet. 44: 135-150.

Suarez, B.K. 1978. The affected sib pair IBD distribution for HLA-linked disease susceptibility genes. Tissue Antigens 12: 87-93.

Thomson, G. and Bodmer, W.F. 1979a. The genetics of HLA and disease associations. In Measuring Selection in Natural Populations, Christiansen, F.B. and Fenchel, T.M., eds., SpringerVerlag, Berlin, pp. 545-564.

Thomson, G. and Bodmer, W.F. 1979b. The genetic analysis of HLA and disease associations. In HLA and Disease, Dausset, J. and Svejgaard, A., eds., Munksgaard, Copenhagen, pp. 84-93.

Thomson, G. 1981. A review of theoretical aspects of HLA and disease associations. Theor. Popul. Biol. 20: 168-208.

Uno, H., Sasazuki, T., Tamai, H., and Matsumoto, H. 1981. Two majorgenes, linked to HLA and Gm, control susceptibility to Graves' disease. Nature 292: 768-770.

Woolf, B. 1955. On estimating the relation between blood groups and disease. Ann. Eugen. 19: 251-253.

Yasuda, N., Komori, K., and Tsuji, K. 1979. Workshop report in genetics. In Proceedings of the First Asia Oceania Histocompatibility Working and Conference, Tsuji, K. and Komori, K., eds., Japan HLA Association, Tokyo, pp. 113-135.

\section{APPENDIX}

Maximum likelihood solution of disease gene frequency when recombination frequency was given.

Since only two degrees of freedom are left for observation and one uses for testing genetic hypothesis, single parameter either gene frequency (p) or recombination fraction (c) (not both) could be estimated from sib pair material. Here we shall consider gene frequency estimation. Iterative method should be pertinent; namely, with a trial value of $p_{0}$ we have the solution $\hat{p}$ as

$$
\hat{\mathrm{p}}=\mathrm{p}_{0}+[\mathrm{U} / \mathrm{K}]_{0}
$$

in which the scores $U$ and $K$ are as follows.

Recessive model.

$$
\begin{aligned}
& \mathrm{U}=\left[\frac{2(1-\phi)}{\mathrm{p}+\phi(1-\mathrm{p})}\right] \mathrm{X}+\left[\frac{1-2 \phi(1-\phi)(1-\mathrm{p})}{\mathrm{p}+\phi(1-\phi)(1-\mathrm{p})^{2}}\right] \mathrm{Y}+\left[\frac{2 \phi}{\phi \mathrm{p}+(1-\phi)}\right] \mathrm{Z}-\left[\frac{2}{1+\mathrm{p}}\right] \mathrm{N}, \\
& \mathrm{K}=\frac{2 \mathrm{~N}\left[\mathrm{p}+\left\{\phi^{2}+(1-\phi)^{2}\right\}\left\{1+\mathrm{p}+2(1-\mathrm{p})^{2} \phi(1-\phi)\right\}\right]}{(1+\mathrm{p})^{2}\left[\mathrm{p}+\phi(1-\phi)(1-\mathrm{p})^{2}\right]}
\end{aligned}
$$

Dominant model.

$$
\begin{aligned}
\mathrm{U}= & {\left[\frac{4-6 \mathrm{q}-3 \mathrm{q}^{2}}{4(1+\mathrm{pq})+\mathrm{pq}^{2}}\right] \mathrm{N}-\left[\frac{1-2(1-\phi) \mathrm{q}-(1-\phi)^{2} \mathrm{q}^{2}}{\mathrm{p}(1+\mathrm{q})^{2}+\mathrm{q}^{2}(2 \mathrm{q}+\phi \mathrm{p})}\right] \mathrm{X} } \\
& -\left[\frac{1-2 \mathrm{q}+\phi(1-\phi) \mathrm{q}(2-3 \mathrm{q})}{1+\mathrm{pq}+\phi(1-\phi) p \mathrm{q}^{2}}\right] \mathrm{Y}-\left[\frac{1-2 \phi(2-\phi) \mathrm{q}-3 \phi^{2} \mathrm{q}^{2}}{1+\mathrm{q}-\phi \mathrm{q}^{2}(2-\phi \mathrm{p})}\right] \mathrm{Z},
\end{aligned}
$$

Jpn. J. Human Genet. 


$$
\begin{aligned}
\mathrm{K}= & \frac{\mathrm{N}}{4(1+\mathrm{pq})+\mathrm{pq}^{2}}\left[\frac{\left\{1-2\left(1-\phi^{2}\right) \mathrm{q}-3(1-\phi)^{2} \mathrm{q}^{2}\right\}^{2}}{\mathrm{p}(1+\mathrm{q})^{2}+\phi \mathrm{q}^{2}(2 \mathrm{q}+\phi \mathrm{p})}\right. \\
& \left.+\frac{8\{1-\phi(1-\phi)+3 \phi(1-\phi) \mathrm{q}\}^{2}}{1+\mathrm{pq}+\phi(1-\phi) p \mathrm{q}^{2}}+\frac{\left\{1-2 \phi(2-\phi) \mathrm{q}-3 \phi^{2} \mathrm{q}^{2}\right\}^{2}}{1+\mathrm{q}-\phi \mathrm{q}^{2}(2-\phi \mathrm{p})}\right] .
\end{aligned}
$$

where $\phi=\mathrm{c}^{2}+(1-\mathrm{c})^{2}$, and $\mathrm{X}, \mathrm{Y}$ and $\mathrm{Z}$ are the observed number of haplotypes sharing two, one or no haplotype identical by descent, respectively. $\mathrm{N}=\mathrm{X}+\mathrm{Y}+\mathrm{Z}$.

The trial value $\mathrm{p}_{0}$ may be chosen the one obtained from the assumption of no recombination. 